\title{
Perencanaan Partisipatif Pembangunan Desa Pejengkolan Kecamatan Padureso Kabupaten Kebumen
}

\author{
Agus Suroso \\ Mahasiswa Program Studi Ilmu \\ Kesejahteraan Sosial Universitas \\ Indonesia \\ asuroso4@gmail.com
}

\section{Ety Rahayu}

Dosen Ilmu Kesejahteraan Sosial

Universitas Indonesia

J1. Margonda Raya, Pondok Cina, Kecamatan Beji, Kota Depok, Jawa Barat 16424

\begin{abstract}
Abstrak
Penelitian ini bertujuan untuk melihat bagaimana proses perencanaan partisipatif pembangunan desa pejengkolan tahun 2019 - 2025. Penelitian ini menggunakan metode kualitatif - deskriptif. Hasil penelitian ini menunjukan bahwa proses perencanaan pembangunan desa dilakukan secara partisipatif melalui musyawarah dusun (musdus), musyawarah desa (musdes), Loka Karya Desa (Lokdes) dan musyawarah perencanaan pembangunan desa (musrenbangdes). Pada proses tersebut menunjukan bahwa setiap tahapan yang dilakukan mulai dari tahapan penyelidikan, perumusan masalah, tahapan identifikasi sumber daya (daya dukung), tahapan perumusan tujuan, tahapan rencana tindakan, dan tahapan penyusunan anggaran telah dilakukan secara bersama - sama pemerintah desa dengan masyarakat. Dalam setiap tahapan, yang menunjukan perencanaan partisipatif atau perencanaan yang melibatkan masyarakat adalah tahapan pengkajian keadaan desa atau tahapan penggalian. Sebab pada tahapan ini masyarakat diberikan kewenangan seluas - luasnya untuk mengusulkan proyek/program sesuai dengan kebutuhan masyarakat dengan melihat potensi, peluang, dan masalah yang dihadapi oleh masyarakat. Sedangkan pada tahap paska pengkajian keadaan desa, tahapan - tahapan berikutnya hanya diikuti oleh perwakilan atau delegasi dari tiap - tiap dusun untuk mengawal usulan menjadi prioritas pembangunan desa selama 6 tahun. Kemudian untuk menentukan prioritas pembangunan dilakukan dengan cara perangkingan yang di nilai oleh masyarakat secara bersama - sama dengan melihat dampak, pemenuhan hak dasar, dan pengaruh dari program yang diusulkan oleh masyarakat desa.

Kata Kunci : Perencanaan,Pembangunan Desa, Perencanaan Partisipatif
\end{abstract}

\section{Abstract}

This study is aimed to observe how the participatory planning process of thedevelopment of Pejengkolan Villageduring 2019 - 2025. This research uses a qualitative - descriptive method. The results of this study indicate that the village development planning process is carried out in a participatory manner through hamlet deliberations (musdus), village meetings (musdes), Village workshop (Lokdes) and village development planning deliberations (musrenbangdes). This process shows that every stage carried out, starting from the investigation stage, the problem formulation, the resource 
identification stage (supporting capacity), the goal formulation stage, the action plan stage, and the budget preparation stage have been carried out jointly with the village government and the community. In each stage, what shows participatory planning or planning that involves the community is the stage of assessing the condition of the village or the stage of excavation. Because at this stage the community is given the broadest possible authority to propose projects / programs according to community needs by looking at the potentials, opportunities and problems faced by the community. Meanwhile, at the post-assessment stage of the village condition, the following stages were only followed by representatives or delegates from each hamlet to oversee proposals to become a priority for village development for 6 years. Then, to determine development priorities, it is done by ranking those assessed by the community together by looking at the impact, fulfillment of basic rights, and the influence of the programs proposed by the village community.

\section{Keywords: Planning, Village Development, Participatory Planning}

\section{PENDAHULUAN}

Tujuan pembangunan Indonesia telah termaktub dalam UU 1945 yaitu untuk melindungi segenap bangsa Indonesia dan seluruh tumpah darah Indonesia, memajukan kesejahteraan umum, mencerdaskan kehidupan bangsa serta ikut dalam melaksanakan ketertiban dunia.

Salah satu tujuan pembangunan adalah untuk mensejahterakan kesejahteraan umum, maka untuk mewujudkan tujuan tersebut dibutuhkan suatu perencanaan yang baik, yaitu perencanaan yang sesuai dengan kebutuhan masyarakat. Midgley (1995: 14) mendefinisikan bahwa kesejahteraan sosial sebagai suatu keadaan atau kondisi kehidupan manusia yang tercipta ketika berbagai permasalahan sosial dapat dikelola dengan baik; ketika kebutuhan manusia dapat terpenuhi dan ketika kesempatan sosial dapat dimaksimalkan. Selain itu Undang - Undang No 11 Tahun 2009 tentang kesejahteraan sosial yang telah mendefinisikan bahwa kesejahteraan sosial adalah kondisi terpenuhinya kebutuhan material, spiritual, dan sosial warga negara agar dapat hidup layak dan mampu mengembangkan diri, sehingga dapat melaksanakan fungsi sosialnya.

Salam (2002:14) berpendapat bahwa perencanaan adalah usaha membuat suatu pilihan tindakan dari berbagai alternatif yang memungkinkan dapat tersedia yang meliputi strategi, kebijakan, program, proyek dan prosedur dalam rangka mencapai tujuan organisasi. 
Secara garis besar perencanaan terdiri dari dua model, yaitu model perencanaan bersifat Top Down dan Bottom Up. Menurut Soetomo, (2011:76) Perencanaan yang bersifat Top Down adalah model perencanaan yang bersifat teknokratik, sedangkan perencanaan yang bersifat Bottom Up adalah perencanaan yang bersifat partisipatif. Hal ini senada dengan pendapat Adi (2007:31) yang mengemukakan bahwa perencanaan partisipatif adalah proses perencanaan yang dimulai dari tahap engagment (persiapan), assesment, dan planning.

Kemudian Abe (2002:71) mengungkapkan bahwa perencanaan partisipatif adalah perencanaan yang dalam tujuannya melibatkan kepentingan masyarakat, dan dalam prosesnya melibatkan masyarakat (baik secara langsung maupun tidak langsung) serta tujuan dan cara harus dipandang sebagai kesatuan. Sebab satu tujuan untuk kepentingan masyarakat bila dalam merumuskan tidak melibatkan masyarakat maka dipastikan rumusan tersebut akan berpihak pada masyarakat.

Desa sebagai struktur pemerintahan paling bawah yang memiliki legitimasi dalam Negara, dituntut untuk menyusun perencanaan pembangunan yang melibatkan masyarakat (perencanaan partisipatif). Sebagaimana Peraturan Pemerintah Tahun 2005 tentang desa pasal 63 ayat 2 yang menyatakan bahwa perencanaan pembangunan desa disusun secara partisipatif oleh pemerintah desa sesuai dengan kewenanganya. Oleh karena itu, dalam menyusun perencanaan tersebut dibutuhkan sinergisitas perencanaan pembangunan desa dengan pembangunan kabupaten/kota, pembangunan provinsi, dan pembangunan nasional secara sistematis, terukur dan tepat sasaran serta sesuai dengan aspirasi masyarakat, kepentingan, dan kebutuhan warga desa.

Menurut Conyers, (1994 : 154 - 155) Ada tiga alasan mengapa perencanaan partisipatif dibutuhkan:

a. Perencanan partisipatif merupakan suatu alat guna memperoleh informasi mengenai kondisi, kebutuhan dan sikap masyarakat setempat yang tanpa kehadiranya program pembangunan serta proyek - proyek akan gagal.

b. Masyarakat akan lebih mempercayai kegiatan atau program pembangunan jika merasa dilibatkan dalam proses persiapan dan perencanaanya, karena mereka akan lebih mengetahui seluk beluk program tersebut dan akan mempunyai rasa memiliki terhadap program tersebut. 
c. Karena timbul anggapan bahwa merupakan suatu hak demokrasi bila masyarakat dilibatkan dalam proses pembangunan.

Dalam menyusun perencanaan partisipatif Abe (2001:100) telah mengemukakan langkah - langkah perencanaan partisipatif yang disusun dari bawah dan digambarkan sebagai tangga perencanaan. Sebagaimana gambar 1.1 dibawah ini:

\section{Gambar 1.1}

Tangga Perencanaan Partisipatif Menurut Abe

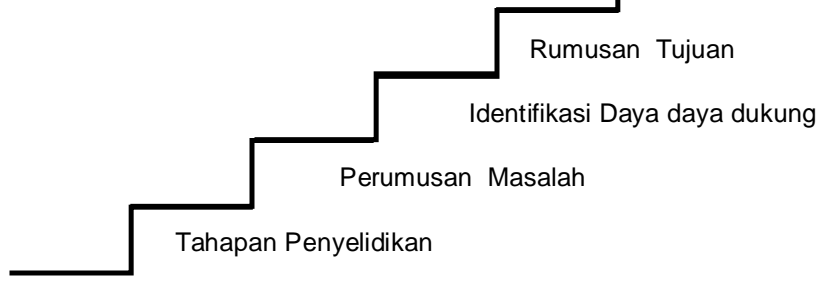

Alexander Abe, 2001:100

Agar lebih mudah dalam memahami teori tangga menurut Alexander Abe dapat dilihat dibawah ini:

1. Tahap Penyelidikan, merupakan sebuah proses untuk mengetahui, menggali dan mengumpulkan persoalan persoalan yang berkembang di masyarakat. Tahap ini sebaiknya merupakan proses pendidikan (penyadaran) bagi masyarakat yaitu, Pertama, Proses yang memungkinkan masyarakat untuk meningkatkan pemahaman masyarakat untuk memahami persoalan - persoalan yang hidup di tengah - tengah mereka. Kedua, Memungkinkan munculnya kesadaran masyarakat mengenai perlunya usaha bersama dalam memecahkan problem yang dihadapi.

2. Tahap Perumusan Masalah, dalam tahap ini data atau informasi yang telah dikumpulkan diolah dan dianalisis untuk menentukan kaitan antara satu fakta dengan fakta yang lain sehingga dapat diperoleh gambaran yang lebih lengkap, utuh dan mendalam. Selain itu dalam tahapan ini juga dilakukan penentuan prioritas yaitu memilih mana segi - segi yang merupakan kebutuhan dasar dari masyarakat (komunitas setempat). Keterlibatan masyarakat dalam tahap 
ini sangat penting agar perumusan masalah dapat dengan tepat mencerminkan kebutuhan kongkrit komunitas yaitu mengenai apa yang dirasakan dan menjadi kebutuhan masyarakat.

3. Tahapan Identifikasi Sumber Daya (Daya Dukung), daya dukung yang dimaksud adalah daya dukung yang tidak terbatas hanya dalam bentuk uang, melainkan juga seluruh aspek yang bisa memungkinkan terselenggaranya aktivitas dalam mencapai tujuan dan target yang telah ditetapkan. Pemahaman mengenai daya dukung ini diperlukan agar rencana kerja yang disusun tidak bersifat asal - asalan, tetapi merupakan hasil perhitungan yang matang.

4. Tahap Perumusan Tujuan, merupakan kondisi kongkrit yang hendak dicapai, yaitu suatu keadaan yang diinginkan (diharapkan, oleh karena itu sejumlah upaya diperlukan untuk mencapainya).

5. Merumuskan rencana tindakan, adalah proses menyusun apa saja yang akan dilakukan, proses ini merupakan proses membuat rumusan yang lebih utuh perencanaan dalam sebuah rencana tindakan. Didalamnya memuat beberapa hal seperti apa yang hendak dicapai, kegiatan yang hendak dilakukan, pembagian tugas atau pembagian tanggung jawab, dan waktu. Hal ini dilakukan agar tidak terjadi perbedaan pendapat dikemudian hari.

6. Penyusun Anggaran, Merupakan suatu usaha untuk menyusun alokasi anggaran atau sumber daya yang tersedia.

Untuk mendorong perencanaan partisipatif sebagaimana yang diatur dalam Peraturan Pemerintah Tahun 2005 tentang desa pasal 63 ayat 2 yang menyatakan bahwa perencanaan pembangunan desa disusun secara partisipatif oleh pemerintah desa sesuai dengan kewenanganya. Dan Undang - Undang No 6 Tahun 2015 tentang Desa, Maka Pemerintah Kabupaten Kebumen dalam hal ini Bupati Kebumen menyusun Peraturan Bupati Kebumen No 31 tahun 2015 tentang petunjuk teknis penyusunan rencana pembangunan desa yang menegaskan bahwa pembangunan partisipatif adalah suatu sistem pengelolaan pembangunan di desa dan kawasan pedesaan yang dikoordinasikan oleh kepala desa dengan mengedepankan kebersamaan, kekeluargaan, dan kegotongroyongan guna mewujudkan pengarusutamaan perdamaian dan keadilan sosial. 
Salah satu langkah nyata yang dilakukan untuk melaksanakan peraturan tersebut maka pemerintah desa pejengkolan kecamatan padureso kabupaten kebumen dalam menyusun perencanaan pembangunan desa atau Rencana Pembangunan Jangka Menengah Desa menggunakan metode perencanaan partisipatif dengan menerapkan mekanisme perencanaan pembangunan desa melalui musyawarah dusun (Musdus), musyawarah desa (Musdes), dan musyawarah perencanaan pembangunan desa (Musrenbangdes).

\section{METODE PENELITIAN}

Penelitian ini dilakukan didesa Pejengkolan Kecamatan Padureso kabupaten Kebumen, Penelitian ini dilakukan sejak bulan agustus sampai bulan november 2019. Adapaun yang menjadi alasan dalam menentukan tempat penelitian dikarenakan Desa pejengkolan di tahun 2015 berhasil meraih juara pertama tingkat nasional pada lomba Perencanaan pembangunan desa partisipatif dan pemberdayaan masyarakat serta lomba Kader Peemberdayaan Masyarakat Desa (KPMD).

Metode yang digunakan dalam penelitian ini adalah kualitatif Dimana tujuan dari penelitian ini adalah untuk memahami secara lebih mendalam tentang bagaimana proses perencanaan partisipatif pembangunan desa yang dilakukan didesa Pejengkolan Kecamatan Padureso Kabupaten Kebumen. Untuk itu diperlukan berbagai informasi, dan data - data empiris yang relevan menganai perencanaan partisipatif untuk diuraikan, digambarkan, dianalisis, dan diinterprestasikan hasil dari penelitian tentang kondisi sebenarnya.

Pendekatan kualitatif berupaya untuk mendapatkan hasil data deskriptif, baik berupa kata - kata tertulis atau lisan dari orang - orang dan perilaku yang dapat diamati dan orang - orang yang memahami masalah, fenomena sosial serta dampak dari situasi yang terjadi. Menurut Creswel (1994:2), penelitian kualitatif idefinisikan sebagai :“... an inquiry process of understanding a social or human problem, based on building a complex, holistic picture, formed with words, reporting detailed views of information, and conducted in a natural setting." (proses pencarian data untuk memahami masalah sosial yang didasari pada penelitian yang menyeluruh (holistic), dibentuk oleh kata-kata, dan diperoleh dari situasi yang alamiah).

Krik dan Miller dalam Moleong (2000:3) mendefinisikan bahwa penelitian kualitatif merupakan suatu metode penelitian 
didalam ilmu sosial yang bergantung secara fundamental pada pengamatan manusia (peneliti) dalam kawasanya sendiri dan berhubungan dengan orang-orang tersebut dalam bahasanya dan peristilahannya.

Penelitian ini bertujuan untuk menggambarkan bagaimana proses perencanaan pembangunan desa dan menjelaskan faktor yang mendorong dan menghambat perencanaan partisipatif.. Berdasarkan tujuan penelitian itu, maka jenis penelitiannya adalah penelitian deskriptif. Penelitian ini mempunyai tujuan untuk memberikan gambaran, deskripsi atau lukisan terhadap suatu permasalahan secara sistematis, sifat-sifat serta hubungan antar fenomena yang diselidiki. Neuman (2016:44) menyebutkan bahwa penelitian deskriptif adalah; "Research in which the primary purpose is to "paint a picture" using words or numbers and to present a profile, a classification of types, or an outline of steps to answer questions such as who, when, where, and how. (Penelitian dimana tujuan utamanya adalah untuk "melukis sebuah gambar" menggunakan kata-kata atau sekumpulan angka dan untuk menampilkan sebuah profil/persoalan, klasifikasi dari tipe-tipe, atau sebuah kerangka dari langkah-langkah untuk menjawab pertanyaan seperti siapa, kapan, dimana, dan bagaimana).

Sedangkan laporan penelitian ini berisi data-data yang memberikan gambaran mengenai jawaban atas pertanyaan penelitian yang dirangkum melalui cara penyajian yang sistematis. Data-data yang ditampilkan bersumber dari naskah wawancara, catatan lapangan, foto, rekaman wawancara, dokumentasi pribadi, catatan atau memo dan dokumen resmi lainnya.

\section{HASIL DAN PEMBAHASAN}

\section{Identifikasi Responden, Sosialisasi dan Pembentukan TIM Pokok Kerja}

Responden dalam penelitian ini adalah pelaku perencanaan pembangunan desa Pejengkolan tahun 2019 - 2025. Berdasarkan hasil observasi lapangan dan berdasarkan hasil wawancara, menunjukan bahwa sebelum dilaksanakan penyusunan rencana pembangunan jangka menengah desa (RPJMDes) tahun 2019 - 2025, pemerintah desa melakukan sosialisasi dan pembentukan Tim Pokok Kerja (TIM POKJA) yang bertugas menyusun perencanaan pembangunan dari musyawarah dusun (Musdus), Musyawarah Desa (Musdes), Loka 
Karya Desa, Musyawarah Perencanaan Pembangunan Desa (Musrenbangdes). TIM POKJA terdiri dari Perangkat Desa, Lembaga Desa, Tokoh Masyarakat dan Unsur Perempuan (Tabel 1).

Tabel. 1 TIM POKJA Desa Pejengkolan

\begin{tabular}{|l|l|l|}
\hline \multicolumn{1}{|c|}{ NAMA } & \multicolumn{1}{c|}{$\begin{array}{c}\text { UNSUR } \\
\text { PERWAKILAN }\end{array}$} & \multicolumn{1}{|c|}{ JABATAN } \\
\hline Muslimah & Kepala Desa & Pembina \\
\hline Puriman & Sekertaris Desa & Ketua Panitia \\
\hline Basir & $\begin{array}{l}\text { Ketua Lembaga } \\
\text { Pemberdayaan } \\
\text { Masyarakat }\end{array}$ & Sekertaris Panitia \\
\hline Turyanto & Perangkat Desa & Anggota \\
\hline Lusinah & $\begin{array}{l}\text { Lembaga Pemberdayaan } \\
\text { Masyarat }\end{array}$ & Anggota \\
\hline Misnem & KPMD & Anggota \\
\hline Tri Murwati & PKK & Anggota \\
\hline Muslim & Tokoh Masyarakat & Anggota \\
\hline
\end{tabular}

Penyusunan perencanaan pembangunan desa yang dilakukan oleh TIM POKJA adalah bentuk dari perencanaan pembangunan yang melibatkan masyarakat, sehingga hasilnya benar - benar sesuai dengan kebutuhan. Menurut Abe (2005:90) dengan adanya keterlibatan masyarakat secara langsung dalam perencanaan memiliki dampak positif yaitu:

1. Terhindar dari terjadinya manipulasi, keterlibatan masyarakat akan memperjelas apa yang sebenarnya dikehendaki masyarakat.

2. Memberi nilai tambah pada legitimasi rumusan perencanaan, yang semakin banyak jumlah masyarakat yang terlibat, maka akan semakin baik hasilnya yang diperoleh.

3. Meningkatkan kesadaran dan keterampilan politik masyarakat. 
Sosialisasi dan pembentukan TIM POKJA dilaksanakan pada tanggal 5 Agustus 2019, Kegiatan ini dilakukan di Balai Desa Pejengkolan Kecamatan Padureso Kabupaten Kebumen. Acara sosialisasi dan pembentukan TIM POKJA dipimpin langsung oleh Ketua BPD, adapun Kepala Desa, Sekertaris Desa, dan perwakilan dari Kecamatan menjadi narasumber untuk meningkatkan pemahaman masyarakat mengenai pentingnya perencanaan pembangunan desa yang melibatkan masyarakat atau disusun bersama - sama.

\section{Penyelarasan arah Kebijakan Perencanaan Pembangunan Kabupaten}

Kegiatan penyelarasan arah kebijakan pembangunan desa merupakan kegiatan yang dilaksanakan oleh TIM POKJA desa pejengkolan sebagai langkah persiapan sebelum pelaksanaan pengkajian keadaan desa atau penyerapan aspirasi masyarakat. Kegiatan ini dimaksudkan, agar nantinya perencanaan yang dilakukan oleh pemerintah desa sinkron dengan visi misi kepala desa dan arah kebijakan perencanaan pembangunan kabupaten.

Sehingga pemerintah desa perlu mendapatkan informasi arah kebijakan pembangunan kabupaten/kota sekurang-kurangnya meliputi:

1. Rencana pembangunan jangka menengah daerah Kabupaten/kota.

2. Rencana strategis satuan kerja perangkat daerah

3. Rencana umum tata ruang wilayah kabupaten/kota

4. Rencana rinci tata ruang wilayah kabupaten/kota.

5. rencana pembangunan kawasan pedesaan.

Kegiatan ini dilakukan dengan cara mendata dan memilih rencana program dan kegiatan pembangunan kabupaten/kota yang akan dimasukan ke desa Dengan cara mengkelompokkan menjadi bidang penyelenggaraan pemerintah desa, pembangunan desa, pembinaan kemasyarakatan desa, dan pemberdayaan masyarakat desa.

\section{Pengkajian Keadaan Desa}

Kegiatan pengkajian keadaan desa dilakukan pada saat musyawarah dusun (Musdus), kegiatan ini merupakan langkah awal dari perencanaan partisipatif, dimana kegiatan ini merupakan tahapan penggalian informasi, potensi yang dimiliki, dan masalah yang dirasakan oleh masyarakat dengan cara memberikan kesempatan 
kepada masyarakat untuk menyampaikan berbagai usulan proyek atau program pembangunan yang dibutuhkan sesuai dengan potensi dan peluang yang dimiliki, dan permasalahan yang dihadapi oleh masyarakat. Berbagai usulan tersebut selanjutnya akan dijadikan bahan pembahasan dalam pelaksanaan musyawarah desa.

Kegiatan ini dilakukan di tiap - tiap dusun sejak 9 agustus 2019 sampai 11 oktober 2019 yang dihadiri oleh perwakilan masyarakat setempat. Adapun metode yang digunakan dalam melakukan pengkajian keadaan desa, TIM POKJA menggunakan metode meta plan. Metode ini dianggap sangat efektif, sebab semua masyarakat bisa mengusulkan program apa saja yang diinginkan. Pada tahap ini, pemerintah desa yaitu kepala desa hanya menjadi narasumber dan memfasilitasi kegiatan tersebut. Sedangkan yang memimpin acara adalah TIM POKJA. Adapun TIM POKJA bertugas untuk mencatat semua usulan masyarakat yang kemudian usulan usulan tersebut menjadi data untuk menyusun rencana pembangunan desa pejengkolan tahun 2019 - 2025 .

\section{Gambar 1.1}

Proses Pengkajian keaadan desa melalui Musyawarah Dusun

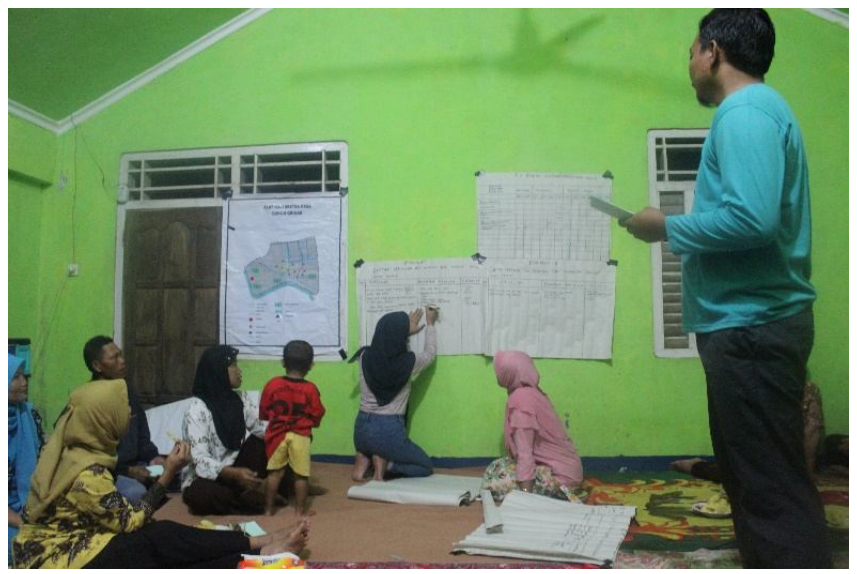

Dengan menggunakan metode meta plan, selain menjadi data untuk menyusun perencanaan pembangunan desa. Data tersebut juga bisa menjadi bukti jika di kemudian hari ada masyarakat yang menso'al pembangunan yang dilakukan oleh pemerintah desa nantinya. Selain itu, dengan menggunakan metode meta plan yang dilakukan disetiap dusun juga menjadi bukti nyata bahwa dalam menyusun perencanaan pembangunan desa di desa Pejengkolan dilakukan sesuai dengan usulan masyarakat atau secara partisipatif. 
Selanjutnya pada tahap ini, selain masyarakat mengusulkan program atau proyek pembangunan desa. Masyarakat juga memilih delegasi untuk mengawal program yang telah diusulkan, agar nantinya usulan mereka dapat terealisasikan. Proses pemilihan dilakukan secara tertutup, yaitu dengan cara menuliskan di kertas yang sudah disediakan oleh TIM POKJA minimal lima (5) orang yang dianggap mampu untuk mewakili masyarakat dusun agar program yang telah diusulkan dapat menjadi prioritas pembangunan desa. Kemudian, dari semua usulan perwakilan yang telah dituliskan, Nama yang terbanyak menjadi perwakilan masyarakat dusun.

Setelah TIM POKJA mendapatkan informasi perencanaan pembangunan desa berdasarkan usulan masyarakat dusun, maka selanjutnya TIM POKJA menyusun laporan hasil pengkajian keadaan desa untuk dilakukan penyusunan rencana pembangunan desa yang dilakukan pada saat musyawarah desa.

\section{Penyusunan Rencana Pembangunan Desa}

Penyusunan rencana pembangunan desa dilakukan pada saat musyawarah desa, kegiatan ini dilakukan pada tanggal 28 Oktober 2019 bertempat di Balai Desa Pejengkolan. Kegiatan penyusunan rencanan pembangunan desa merupakan proses penyusunan draft rancangan dokumen Rencana Pembangunan Jangka Menengah Desa (RPJMDes) tahun 2019 - 2025 yang dipimpin oleh Badan Permusyawaratan Desa (BPD).

Kegiatan tersebut dihadiri oleh Kepala Desa, Perangkat Desa, Pengurus Badan Permusyawaratan Desa (BPD), perwakilan dari lembaga desa, tokoh masyarakat, dan perwakilan dari tiap-tiap dusun yang didelegasikan oleh masyarakat untuk mengawal usulan perencanaan program pembangunan desa.

Proses musyawarah desa dipandu oleh TIM POKJA untuk membahas hasil laporan pengkajian keadaan desa, merumuskan arah kebijakan pembangunan desa yang dijabarkan dari visi misi kepala desa, dan menentukan prioritas pembangunan desa berdasarkan bidang penyelenggaraan pemerintahan desa, pembangunan desa, pembinaan kemasyarakatan desa, dan pemberdayaan masyarakat desa.

Pada tahap ini, kegiatan dilakukan dengan cara diskusi kelompok dan setiap kelompok di fasilitasi atau dipandu oleh TIM POKJA, Kegiatan ini bertujuan untuk membahas laporan hasil pengkajian keadaan desa yang dilakukan oleh TIM POKJA. 
Selanjutnya menentukan priorita pembangunan desa selama 6 tahun. Dalam menentukan prioritas pembangunan desa TIM POKJA melakukan perangkingan dengan melihat pertama, dampak . Apakah dampaknya itu dirasakan satu desa atau satu dusun atau satu KK. Kedua, pengaruh pemenuhan hak dasar, semisal kesehatan, pendidikan. Ketiga, pengaruh terhadap angka kemiskinan. Adapun nominal perankingan $1-100$.

Pada Tahap ini, semua masyarakat melakukan penilaian secara bersama - sama. Sehingga dari hasil perangkingan dengan jumlah tertinggi akan menjadi prioritas pembangunan selama 6 tahun. Selanjutnya TIM POKJA menyusun asumsi pendapatan anggaran desa dengan cara menambahkan $10 \%$ anggaran tahun sebelumnya, hal ini dilakukan untuk menganggarkan pembagian program pembangunan desa. Kegiatan ini dilakukan untuk menyusun prioritas pembangunan di setiap tahunnya. Selainn itu untuk menyusun rencana pelaksana kegiatan desa yang akan dilaksanakan oleh perangkat desa, unsur masyarakat, kegiatan yang dilakukan bersama antar desa, dan atau kerjasama desa dengan pihak ketiga.

Gambar 1.2

Proses Penyusunan rencana pembangunan desa dilakukan pada saat musyawarah des

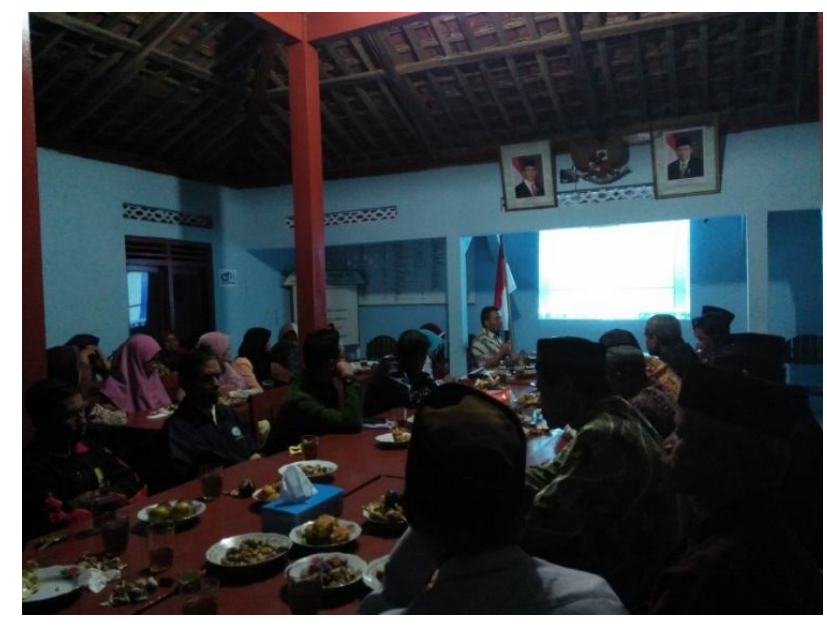

\section{Penyusunan rancangan RPJM Desa}

Kegiatan penyusunan rancangan RPJM Desa dilakukan pada saat loka karya di Balai Desa Pejengkolan pada tanggal 01 dan 13 Bulan November 2019. Pada tahapan ini TIM POKJA menyusun 
rancangan RPJM Desa berdasarkan hasil pembahasan Penyusunan rencana pembangunan desa yang dilakukan pada saat musyawarah desa yang dilampiri dokumen rancangan RPJM Desa untuk disampaikan oleh TIM POKJA kepada kepala desa.

Selanjutnya setelah draft penyusunan rancangan RPJMDes di serahkan ke kepala desa, maka selanjutnya kepala desa memeriksa dokumen tersebut, dan jika ada kekurangan dalam penyusunan rancangan RPJMDes maka kepala desa mempunyai kewenangan untuk meminta kepada TIM POKJA agar diperbaiki dokumen tersebut, sampai kepala desa menyetujui dokumen tersebut untuk di bawa pada tahapan penyusunan rencana pembangunan desa yang dilakukan pada saat musyawarah perencanaan pembangunan desa (Musrenbangdes).

Gambar 1.3

Proses penyusunan rancangan RPJM Desa pada Loka Karya Desa

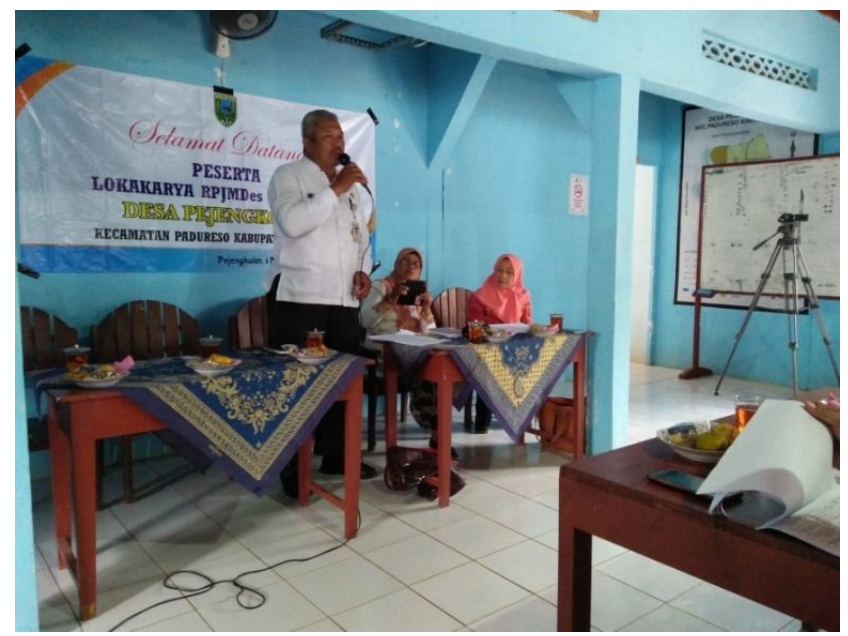

\section{Penyusunan rencana Pembangunan Desa}

Kegiatan Penyusunan perencanaan pembangunan desa atau Musyawarah perencanaan pembangunan desa (Musrenbangdes) desa pejengkolan telah dilaksanakan pada tanggal 26 November 2019, yang bertempat di Balai Desa Pejengkolan kecamatan padureso kabupaten kebumen. Maksud dan tujuan kegiatan ini adalah untuk membahas dan menyepakati rancangan RPJM Desa tahun 2019 - 2025.

Selanjutnya hasil dari kesepakatan musyawarah perencanaan pembangunan desa dituangkan dalam berita acara untuk ditetapkan menjadi Peraturan Desa tentang RPJM Des yang berlaku selama enam 
(6) Tahun. Acara tersebut dihadiri oleh perangkat desa, Badan Permusyawaratan Desa (BPD), dan beberapa unsur masyarakat.

\section{Penyepakatan Dan Penetapan Perdes RPJM Desa}

Pada tahapan ini Kepala Desa mengarahkan Tim Pokja untuk melakukan perbaikan dokumen rancangan RPJMDes berdasarkan hasil kesepakatan musyawarah perencanaan pembangunan desa (Musrenbangdes). Sedangkan rancangan RPJMDes menjadi lampiran rancangan peraturan desa tentang RPJM Desa. Selanjutnya Kepala Desa menyusun rancangan peraturan Desa tentang RPJMDes untuk disepakati bersama oleh Kepala Desa dan Badan Permusyawaratan Desa (BPD) untuk ditetapkan menjadi Peraturan Desa tentang RPJM Desa.

RPJM Desa dapat dirubah oleh Kepala Desa apabila terjadi peristiwa khusus seperti bencana alam, krisis politik, krisis ekonomi, kerusuhan sosial yang berkepanjangan, atau adanya perubahan kebijakan pemerintah Kabupaten, Provinsi, Pusat.

\section{Kesimpulan}

1. Proses perencanaan pembangunan desa tahun 2019 - 2025 di desa pejengkolan dilakukan secara partisipatif.

2. Proses perencanaan pembangunan desa pejengkolan jika dikaitkan dengan teori alexander abe tentang tangga perencanaan yang disusun dari bawah sebagaimana dibahas dilatar belakang maka bisa diambil kesimpulan, proses perencanaan tersebut sangat relevan dari tahap penyelidikan, tahap perumusan masalah, tahap identifikasi sumber daya dukung, tahap perumusan tujuan, tahap merumuskan rencana tindakan, dan tahap penyusunan anggaran telah dilakukan oleh pemerintah desa pejengkolan bersama - sama dengan masyarakat. Walaupun pada pasca tahap pengkajian keadaan desa dilakukan bersama - sama delegasi dari tiap - tiap dusun.

Daftar Pustaka 


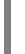

A Friedlander, Walter. Pengantar Kesejahteraan Sosial Jakarta: Gema Insani Press, 1961

Adi, Isbandi Rukminto (2002). Pemikiran-pemikiran dalam pembangunan kesejahteraan sosial. Jakarta: Fakultas Ekonomi, Universitas Indonesia.

Adi, Isbandi Rukminto (2012) . Pengantar Kesejahteraan Sosial. Bandung: Refika Aditama.

Adi, Isbandi Rukminto. (2013). Intervensi komunitas: Pengembangan masyarakat

Adi, Isbandi Rukminto. (2015). Kesejahteraan sosial: Pekerjaan sosial, pembangunan sosial dan kajian pembangunan. Jakarta: Rajawali Pers.

Adisasmita, Rahardjo. (2006). Pembangunan perdesaan dan perkotaan. Yogyakarta: Graha Ilmu.

Alexander Abe (2005). Perencanaan Daerah Partisipatif. Yogyakarta: Pembaharuan

Allen, Louis. 1958. A Management and Organization. New York: McGraw Hill Book Company

Alston, P dan Bowles, JE. (2004). Social Method and Reseach Analysis. London: Cambridge University Press.

Arikunto, Suharsimi. 1996. Metode Penelitian: Suatu pendekatan Praktek. Jakarta: PT. Rineha Cipta.

Arnstein, Sherry. 1969. A Ladder of Citizen Participation. Journal of the American Planning Association, Volume 35

Arsyad, L. (1999) Pengantar Perencanaan Pembangunan Ekonomi Daerah, Edisi Pertama, BPFE, Yoyakarta.

Barquero, Antonio Vazquez. (2002). Endogenous development: Networking, innovation, institustion and cities. New York: Routledge. 
Barquero, Antonio Vazquez. (2002). Endogenous development: Networking, innovation, institustion and cities. New York: Routledge.

Briyant dan White (1987). Manajemen Pembangunan Untuk Negara Berkembang terj. Rusyanto L. Simatupang: LPES

Bryman, Alan. (2012). Social reseach methods. 4th edition. New York: Oxford University Press.

Chapin . J.P. (2002). Kamus Lengkap Psikologi. Cetakan Keenam. Penerjemah: Kartiko, K. Jakarta: PT. Raja Grafika Persada

Cohen, J.M, and N.T. Uphoff (1997). Rural Development Participation. New York: Ithaca.

Conyers, Diana (1991). Perencanaan Sosial di Dunia Ketiga. Yogyakarta: Gajah Mada University Press.

Creswell, J. W. (1994). Research design: quantitative and qualitative approach. London: Sage Publication.

Creswell, J.W. (2020). Reseach Desidn (Pendekatan Kualitatif, Kuantitatif, dan Mixed). Yogyakarta: Pustaka Pelajar

David C. Korten (1984). Pembangunan yang memihak Rakyat: Kupasan Tentang Teori dan Metode Pembangunan, dialihbahasakan oleh Lembaga Studi Pembangunan (LSP), Yayasan Studi Pembangunan, Jakarta.

Davis, Kaith, (1962), Human Relation at Work, Mc. Graw Hill Book, co. Inc. Kogakhusa Co. Ltd. Tokyo.

Fahrudin, Adi (2012). Pengantar Kesejahteraan Sosial. Bandung: Refika Aditama

Fahrudin, Adi 2001. Pemberdayaan partisipasi dan penguatan kapasitas Masyarakat. Bandung. Humaniora

Friedlander, Walter A dan Apte, Robert Z. 1982. Introducing Sosial Walfare. New Delhi. Precentile Hall of India

Ginanjar, Kartasasmita (1997). Kemiskinan . Jakarta : Depdiknas 
Hasan, Iqbal. M. 2002. Metodologi Penelitian dan Aplikasinya, Jakarta. Ghalia Indonesia.

Hobley, M. (1996). Participatory Forestry: The prosess of change in India and Nepal Development Forestry Study Guide 3. London: Rural Development Forestry Network.

Holil, Soelaiman , (1980). Partisipasi sosial dalam Usaha Kesejahteraan Sosial. Bandung: Badan Penelitian dan pengembangan sosial

Hadi, Sudarto, 2001, Dimensi Lingkungan Perencanaan Pembangunan, Yogyakarta : Gajah Mada University Press

Ife, Jim dan Frank Tesoriero. (2006). Community development: Community-based alternatives in an age of globalisation, (3rd edition). NSW: Perarson Education.

Ife, Jim. (2013). Community development in an uncertain world: Vision, analysis and practice. New York: Cambridge University Press.

Islamy, Irfan, 1997, Prinsip - Prinsip Perumusan Kebijakan Negara, Bumi Aksara, Jakarta.

Kaho, Josef. 2007. Prosfek Otonomi Daerah di Daerah Republik Indonesia. Jakarta: PT Raja Grafindo.

Krefting, L (1990:217). Rigor in Qualitative Reseach: The Assesment Of Trustworthines, Article was accepted for publication.

Midgley, James. (1995). Social development: The development perspective in social welfare. California: Sage Publication.

Mikkelsen, Britha (1990). Metode Penelitian Partisipatoris dan Upaya pemberdayaan. Yayasan Pustaka Obor Indonesia. Jakarta.

Moelong, Lexy J. 2000. Metode Penelitian Kualitatif. Bandung: PT. Remaja Rosdakarya

Mubyarto (1997). Ekonomi Rakyat, Program IDT, dan Demokrasi Ekonomi Indonesia. Aditya Media. Yogyakarta 
Mubyarto dan Sartono Kartodirjo. (2005). Pembangunan Pedesaan di Indonesia. Yogyakarta: Liberty dan P3PK Universitas Gajah Mada.

Muhidin, Syarif. 1997. Pengantar Kesejahteraan Sosial. Cetakan Ke VII. Bandung. Percetakan Mitra Anda

Ndraha, Talizidhuhu. 1987. Metodologi Pembangunan Indonesia. Jakarta. PT Bina Aksara

Ndraha, Talizidhuhu. 1987. Pembangunan Masyarakat. Jakarta. Jakarta. Rineka Cipta

Neuman, W. Lawrence. (2016). Social resear222 ch methods: Qualitative and quantitative approaches (7th ed). University of Wisconsin, Whitewater: Pearson Education, Inc.

Oakley, Peter, et al. 1991. Project with people the pratice of participation in rural Development. General: International Labour Office.

Pasaribu, I.L., Simanjuntak, B. 2005. Sosiologi Pembangunan, Bandung: Tarsito

Poerwandari, E.K (2007). Pendekatan Kualitatif dalam penelitian Psikologi. Jakarta: LPSP3 Universitas Indonesia

Sastropoetra, Santoso R.A (1988). Parisipasi, Komunilasi, Persuasi, dan Disiplin Dalam Pembangunan Nasional. Alumni Bandung. sebagai upaya pemberdayaan masyarakat. Jakarta: Rajawali Pers.

Siporin, Max. 1972. Intriduction to Social Work Practice. New York:Mc Millan.

Skidmore, Rex A, dkk. 1974. Introduction to Social Work. Fith Edition. New Jersey: Prentice-Hall International Editions.

Spicker,P (1995) Social Policy: Themes and Approaches. London: Prentice Hall.

Sumodiningrat, Gunawan (1998). Membangun Perekonomian Rakyat, (Yogyakarta: Pustaka Pelajar) 
Sumudiningrat, G. (2000) Visi dan Misi Pembangunan Pertanian Berbasis Pemberdayaan, Yogyakarta: IDEA

Terry, George R. (1991) Prinsip-Prinsip Manajemen, Bumi Aksara, Jakarta.

Tjokroamidjojo, Bintaro (1996). Perencanaan Pembangunan, Perpustakaan Fisipol, Jakarta.

Wilcox, C.F, and Wilcox, M.F. 1995. Experimental Organic Chemistry. Prentice-Hall, New Jersey.

Wilcox, David, 1994. The Guide to Effective Participation. London: Delta Press

Zastrow, Charles. (2010). Social work and social welfare. Canada: Brooks/Cole, Cengage Learning.

Undang-undang Dasar 1945

Undang-undang No 11 Tahun 2009 Tentang Kesejahteraan Sosial

Undang-undang No. 25 Tahun 2004 tentang Sistem Perencanaan Pembangunan Nasional

Undang-undang nomor 6 tahun 2014 Tentang Desa

Peraturan Menteri Dalam Negeri No. 114 tahun 2014 Tentang Pedoman Pembangunan Desa

Peraturan Menteri Dalam Negeri Tahun 2010 Tentang Pelaksanaan Peraturan Pemerintah Nomor 8 Tahun 2008 Tentang Tahapan, Tatacara Penyusunan, Pengendalian, Dan Evaluasi, Perencanaan pembangunan daerah

Peraturan Menteri Desa dan Pembangnan Daerah Tertinggal dan Transmigrasi No. 1 Tahun 2015

Peraturan Pemerintah No. 72 Tahun 2005 Tentang Desa Tentang Rencana Pembangunan Jangka Menengah Desa Tahun 2019 2025

Peraturan Bupatei Kebumen Nomor 31 Tahun 2015 tentang Petunjuk teknis Penyusunan Rencana Pembangunan Jangka Menengah Desa dan Rencana Kerja Pemerintah Desa 